\title{
NATURAL POLYMERS ON THE GLOBAL AND EUROPEAN MARKET - PRESENTATION OF RESEARCH RESULTS IN THE ŁUKASIEWICZ RESEARCH NETWORK - INSTITUTE OF BIOPOLYMERS AND CHEMICAL FIBERS-CASE STUDIES ON THE CELLULOSE AND CHITOSAN FIBERS
}

\author{
Radosław Dziuba', Katarzyna Grabowska², Dariusz Wawro ${ }^{3}$, Justyna Wietecha ${ }^{3}$, Zofia Wysokińska ${ }^{1}$ \\ 1 Faculty of Economics and Sociology, Department of World Economy and European Integration, University of Lodz, Łódź, Poland \\ 2 Faculty of Material Technologies and Textile Design, Technical University of Lodz, Łódź, Poland \\ 3Łukasiewicz Research Network - Institute of Biopolymers and Chemical Fibres, Łódź, Poland \\ ${ }^{*}$ Corresponding author. E-mail: radoslaw.dziuba@uni.lodz.pl
}

\begin{abstract}
:
The paper aims to present the main tendencies on the global and European natural polymer markets in recent years from the point of view of the requirements and achievements of the European Commission that have been expressed in recent programs and Strategies, with special reference to the Circular Economy New Action Plan and the European Green Deal-the EU Strategies for Climate Neutrality. Natural polymers play an important role among biodegradable products whose role in the production and international trade has been systematically increasing, especially since the middle of the last decade of the new century (2015). Natural polymers are also recommended by the EU from the point of view of their specific importance in the group of biodegradable products.
\end{abstract}

\section{Keywords:}

Global market, European Union Market, circular economy, Eco-design, European Green Deal

\section{Introduction}

In recent years, the natural polymers market has become a good developing market in the modern world and European economy. Natural polymers play an important role among biodegradable products whose role in the production and international trade has been systematically increasing, especially since the middle of the last decade of the new century (2015). Natural polymers are also recommended by the EU from the point of view of their specific importance in the group of biodegradable products. The leaders of the global export market of natural polymers include China, the USA, Sweden, France, Italy, Germany, The Netherlands, Japan, Spain, Denmark, Singapore, Czech Republic, Belgium, Canada, Thailand, Israel, Switzerland, South Korea, Brazil, and Poland (cf. test results presented in the Statistical Annex).

The article is divided into two parts: The first part presents the results of the analysis of foreign trade in natural polymers at the global and European level, while the second part presents case studies of the results of research on natural polymers and their application in economic practice based on the achievements of the Łukasiewicz Network-Institute of Biopolymers and Chemical Fibers.

\section{Part I: Natural polymers on global and European market-results of foreign trade analysis}

\section{Introduction}

In the new Action Plan of the European Union (EU), concerning the circular economy for a greener and more competitive Europe, the European Commission announced that it would undertake initiatives to restore natural resources to the economy, and concerning the entire life cycle of products, from the design and production stage to their use, repair, reuse, and recycling. The EU plan addresses areas where action at the supranational level adds value. This plan forms the basis of the European Green Deal-the EU Strategy for Climate Neutrality. Half of all greenhouse gas emissions come from the extraction and processing of resources. Achieving the climate neutrality goal by 2050 will not be possible without a full transition to a circular economy. Between 1970 and 2018, global extraction and processing of raw materials such as fossil fuels, metals, and minerals tripled and continues to grow, causing greenhouse gas emissions, loss of biodiversity, and water stress. A circular economy model, where value and resources remain in the economy for as long as possible and the generation of waste is limited, reduces pressure on natural resources and encourages the production of biodegradable products as well as environmental protection, including, in particular, respect for biodiversity. The Action Plan adopted 
a number of proposals for a range of industries for which a comprehensive policy framework was announced that will aim to strengthen industrial competitiveness and eco-innovation by supporting the EU market for more durable products and the re-use of waste to make new products. Natural polymers play an important role among biodegradable products, whose role in the production and international trade has been systematically increasing, especially since the middle of the last decade of the new century (2015).

\section{Analysis of trends on the global and European market of natural polymers}

This part of the article aims to present the results of the analysis concerning the dynamically developing global and European market of natural polymers in recent years. The research and analysis of the research results were carried out using the statistical data of EUROSTAT and Comtrade-UN databases for 2018-2019 for world imports and exports, broken down into major importers and exporters of polymers. The analysis took into account both the values of imports and exports, the dynamics of imports and exports of individual trading partners, and their share in global imports and exports in the analyzed years. The research results for the EU countries and Poland were analyzed and assessed similarly. The global exports of natural polymers in the latest years of 2018-2019 where data is available amounted to approximately USD 2 billion and showed a growing tendency. The first group of the 20 largest exporters of these polymers in the last analyzed year 2019 was China, the USA, Sweden, France, Italy, Germany, Netherlands, Japan, Spain, Denmark, Singapore, Czech Republic, Belgium, Canada, Thailand Israel, Switzerland, South Korea, Brazil, and Poland. Other countries exporting natural polymers worth more than USD 1 million are Great Britain, India, Ireland, Russian Federation, Estonia, Iceland, Vietnam, Malaysia, Portugal, South Africa, Argentina, Australia, Lithuania, ChinaHong Kong, Peru, Slovenia, and Taiwan (see Table 1) in the Statistical Annex.

It should be emphasized that the dominant position in the global market of natural polymers was held by China, the USA, and Sweden (totaling an almost $56 \%$ share in it), and after additionally including the exports of France, Italy, Germany, and the Netherlands, the total share in the global market of the above-mentioned countries exceeded $80 \%$ (see Table 1).

The analysis of the dynamics of exports of natural polymers in 2019 compared to 2018 shows that several developing countries or countries transforming their economies towards a market economy (countries in transition), such as Mauritius, Azerbaijan, the Russian Federation, Ecuador, Cyprus, Namibia, and Georgia, displayed particularly high export growth. This can be explained by the dynamic development of their exports as a result of many international corporations locating their production in these countries.

The EU (27) is one of the leading players in the global export market of natural polymers, with almost half of the share $(50 \%)$ among all countries in the world in 2019. The market leaders in the EU were three countries, i.e., Sweden, France, and Italy (the total share of these countries in the EU export of natural polymers amounted to $31.3 \%$ ). The following eight countries were among the next group of the largest exporters of natural polymers in the EU: Germany, the Netherlands, Spain, Denmark, the Czech Republic, Belgium, and Poland (on a par with Ireland). The share of the ten largest exporters of natural polymers in the EU reached the level of $47.9 \%$ among all 27 EU member states in the year 2019 (see Table 2).

Poland is one of the major exporters of natural polymers, reaching the twentieth position in world exports in 2019, with high export dynamics in 2019 compared to the previous year, exceeding $18 \%$. The main recipients of natural polymers exported from Poland were four countries, i.e., Germany, Denmark, Great Britain, and the United Arab Emirates. Exports to these countries accounted for $46.8 \%$ of the total exports of natural polymers from Poland. Other recipients in the top 10 include Mexico, the Czech Republic, France, Spain, the Russian Federation, and Belarus. Italy, Cyprus, Ukraine, the Netherlands, Egypt, and India occupied a further position (see Tables 1, 4, and 5).

The global import demand for natural polymers was in the last years where data is available for 2018-2019 at the level of over USD 2 billion was characterized by a growing trend. The top ten importers of this product group were the USA, Japan, Germany, South Korea, France, China, Belgium, Switzerland, the Netherlands, and Spain, whose share in global imports exceeded $61 \%$ in 2019 . Further positions exceeding the share of $1 \%$ in global imports were taken by the following countries: Italy, Russian Federation, Great Britain, Canada, Mexico, Singapore, Brazil, Saudi Arabia, India, Thailand, and Taiwan. ${ }^{1}$

Poland has the 25th position in the world import of natural polymers. The analysis of the dynamics of import of natural polymers in 2019 compared to 2018 shows that several developing countries are transforming their economies towards a market economy (countries in transition); in particular, Mauritania, Saint Vincent and the Grenadines, Serbia, Samoa, Comoros, Romania, and Azerbaijan recorded a particularly high export dynamics, which can be explained (as has already been mentioned in the case of exports) by the dynamic development of trade flows of international corporations locating their production in these countries under outsourcing ${ }^{2}$.

The EU (27) is one of the major players in the global import market for natural polymers, with almost a third of the share in 2019 (32.1\%, with a slight downward trend compared to 2018 , when its share was $32.2 \%$ ). The top ten importers of natural polymers in the EU include Germany, France, Belgium, the Netherlands, Spain, Italy, Sweden, Poland, Austria, and Denmark. The share of this group of countries is almost $29 \%$ of the global import of natural polymers in 2019. The remaining EU27 countries accounted for only approximately $3 \%$ of the global import of the analyzed group of polymers (see Table 3 ).

\footnotetext{
$1 \quad$ Own elaboration based on Comtrade Database, SITC rev. 4; https://comtrade.un.org/data/; date of access: 2020.10.27.

2 As above
} 
Poland imports natural polymers mainly from China, Sweden, and the USA, from which more than $50 \%$ of the supplies of this product come. Important suppliers are also countries such as Pakistan, Germany, Saudi Arabia, France, Austria, Denmark, Italy, the Netherlands, Israel, South Korea, Taiwan, and the United Kingdom. The share of these countries in the import of natural polymers by Poland constitutes about $40 \%$ of other foreign supplies (see Table 6). Among the $27 \mathrm{EU}$ member states, Poland was ranked 8th in imports (see Table 7).

\section{Part II: Results of the research analysis of natural polymers in the Łukasiewicz Research Network-Institute of Biopolymers and Chemical Fibers}

\section{Cellulose as the most widely used natural polymer in the world}

Cellulose is the most common natural polymer in the world. Currently, several fibrous plants are used globally on an industrial scale. These include cotton (CO), linen, hemp, kenaf, jute, and sisal. However, this biopolymer is most often obtained from wood material. A valuable source of this raw material can also be waste plant biomass, e.g., straw residues after harvesting of annual plants [1]. In accordance with the current economic policy, but above all, taking into account an ecological approach to the economy, the raw materials must be obtained locally so that they constitute one of the elements of the "circular economy." According to the Polish Statistical Office, in 2018 the production of wheat grain in Poland, besides other cereals, amounted to over 110 million tons [2]. In the case of wheat the grain/straw ratio is on average $1: 1$, so even assuming that about half of the straw is utilized (left in the field as a natural fertilizer, used as fodder), tens of millions of tons of valuable raw material are left for disposal.

Cellulose is a valuable material not only in the pulp and paper industry. It can be used to produce intermediates such as nanoparticles, nanowhiskers, or cellulose nanofibers. Łukasiewicz-IBWCh has developed a technology for the treatment of textile industry wastes and annual plant stems to obtain cellulose micro/nanofibers (EP 3172378). The stems purified from non-cellulosic fractions were subjected to enzymatic treatment using cellulolytic complexes, which contributed to the reduction of the number and/or energy of intermolecular hydrogen bonds of cellulose. This facilitated the penetration of water molecules into the pulp and better swelling of the fibers and thus facilitated further mechanical defibration. Using two-stage enzymatic and mechanical treatment, it was possible to obtain nanofibers with a diameter in the range of 25-400 nm and a length from several hundred nanometers to several micrometers [1, 2]. The obtained nanofibers were used as a filler improving the sound-absorbing parameters of composites with a thermoplastic matrix (PL 227654). The developed layered composite is constructed of alternately arranged layers of needle-punched non-woven consisting of standard staple fibers, cellulose micro/nanofibers, which constitute up to $30 \%$ of the weight of the composite and a thermoplastic polymer. In the case of the composite with cotton (CO) fibers content of $50 \%$ and cellulose micro/nanofibers, the sound absorption coefficient in the frequency range of 500 $2,500 \mathrm{~Hz}$ increases to about 0.8 , and in the range of 2,500$6,000 \mathrm{~Hz}$, it is almost constant $[3,4]$.

Another source of cellulose nanofibers can also be so-called bacterial cellulose (BC) produced by some strains of bacteria, in particular, from the genus Komagataeibacter xylinus. BC is synthesized extracellularly in the form of microfibrils that connect to each other by strong hydrogen bonds, resulting in a network of highly entangled nanofibers. Cellulose obtained in the biosynthesis process is characterized by high purity as it contains no lignins, no pectins, no hemicelluloses, high crystallinity index, and average polymerization degree, which distinguishes it from plant cellulose. In Łukasiewicz-IBWCh the research has been conducted for many years on the production of $\mathrm{BC}$ modified by chitosan (MBC) at the stage of biosynthesis $[1,2]$. Modified nanobiocellulose can have numerous medical applications such as occlusive hydrogel dressings [3], blood vessel prostheses [4], or multilayer surgical meshes for hernia treatment that have been developed in Łukasiewicz-IBWCh $[5,6]$. The above-mentioned hydrogel dressings, owing to the content of chitosan, showed bactericidal and bacteriostatic activity against Escherichia coli and Staphylococcus aureus, which is an extremely important feature when applied to hard-to-heal wounds. Tests of wound dressings based on modified BC on guinea pigs showed good stimulation of factors accelerating the formation of granular tissue, good adaptability to the wound sites of different shapes, and good wound isolation from the environment, thus protecting against secondary infection [7]. Blood vessel prostheses have been developed, both made of modified BC and composite ones, where cellulose was a seal for a polyester pleated sheath used as a reinforcement of the veins. The biological tests carried out showed that these prostheses did not show any cytotoxic, irritating and sensitizing action, or intradermal reactivity [8]. Light polypropylene mesh was the substrate for the developed meshes for hernia treatment. Modified BC acted as a mesh seal, which prevented overgrowth of the mesh by scar tissue and foreign body reaction [9]. In Łukasiewicz-IBWCh the research was also carried out on the use of MBC for the production of loudspeaker membranes. This acoustic membrane was the key element of the loudspeaker, which converted the electrical signal into an acoustic signal in the middle, high, and highest frequencies of the acoustic band. This novel loudspeaker could substitute both the midrange loudspeaker and a tweeter, which are commonly used in loudspeaker systems. This allowed for a significant reduction in the cost of the loudspeaker system, simplification of the electric crossover, as well as improvement of its subjective parameters, because, among others, one source of the acoustic signal is obtained in the medium, high, and highest frequency range [10].

Wider industrial use of BC, especially in non-medical applications, is limited due to the high cost of medium components and relatively low biosynthesis efficiency-the wet film contains only $0.5-1.0 \%$ cellulose, the remainder is water bound to the structure. Hence the new direction of research emerged in relation to the development of nutrient media based on plant waste materials. In Łukasiewicz-IBWCh, the research is conducted on the preparation of $B C$ on substrates 
prepared on the basis of food industry wastes as well as liquid and solid waste remaining after the separation of cellulose fibers from the Spartium junceum plant. Post-maceration fluid obtained from the enzymatic retting of $S$. junceum can effectively replace the water in the liquid nutrient medium used for bacterial biosynthesis of cellulose. The use of the waste stream from the processing of plant biomass meets the idea of a biorefinery and allows obtaining $\mathrm{BC}$ with higher efficiency than on the standard Hestrin-Schramm medium [1].

In Łukasiewicz-IBWCh, during the biorefining of plant biomass, not only cellulose was isolated but also another group of polysaccharides called hemicelluloses. Research results show that hemicellulose fractions, depending on the share of individual polysaccharides, have bacteriostatic or plant growth stimulating properties. Besides, they can be used as bioactive additives in composite materials based on biodegradable polymers [2].

\section{Cellulose fibers}

From the beginning of its activity, at the Institute of Biopolymers and Chemical Fibers, research and development work into the production of cellulose fibers was carried out. Until the 1990s of the twentieth century, these were cellulose fibers produced by the viscose method. The Institute has a specialized pilot-scale line from Blaschke (Germany) for the production of viscose spinning solution and a spinning machine for the formation of cellulose fibers. Based on this pilot line, it was possible to improve the viscose process and study the influence of various pulps on the properties of viscose spinning solution and cellulose fibers. The developed new spin finish compositions and spinning methods were implemented in the following viscose fiber factories in Poland: "Wistom" in Tomaszów Mazowiecki, "Chodakowskie ZWCh" in Sochaczew, "Wiskord" in Szczecin, "Celwiskoza" in Jelenia Góra, and "Viscoplast" in Wrocław.

In the early 1990s, there was a new period of intense research in the development of technologies alternative to viscose for the production of cellulose fibers. The management of the Institute put main emphasis on the development of a Polish method of cellulose carbamate synthesis. Several methods have been developed for the synthesis of carbamate based on the pulp used in the above-mentioned cellulose fiber plants [patents xx]. High quality of carbamate, homogeneity, and high nitrogen content $(2.5-3.0 \%)$ allowed for the preparation of stable alkaline solutions with high polymer content up to $14 \%$, from which staple and continuous fibers and films were formed [1-7]. In the Viscoplast plant in Wrocław, lines for the production of cellulose carbamate were built, which allowed for industrial trials of fiber formation. In "Wistom" in Tomaszów Mazowiecki the batches of staple fibers were produced from alkaline carbamate solutions of appropriate purity. The "Viscoplast" plant in Wrockaw produced batches of adhesive wound plasters based on fibers made with the carbamate method. At the same time, research on rayon formation was carried out at the "Wiskord" plant in Szczecin from alkaline solutions of cellulose carbamate. The advantage of alkaline carbamate solutions was the possibility of mixing them with viscose solutions in various ratios [10]. The mechanical properties of rayon obtained from cellulose carbamate were comparable to those of viscose rayon. The Institute's achievements in the synthesis of cellulose carbamate and the production of fibers allowed for establishing international cooperation, initially with a scientific institute and a company producing cellulose rayon from Slovakia, and then with Zimmer AG from Germany.

It was possible to obtain high-quality cellulose carbamate on the basis of previously activated cellulose. Many methods of cellulose activation have been investigated, ranging from alkaline, enzymatic, hydrothermal to radiation treatment [11].

Parallel to the cellulose carbamate synthesis, the studies were carried out to obtain cellulose directly soluble in an aqueous solution of sodium hydroxide $(\mathrm{NaOH})$ based on the experiments of Kamide, who dissolved cellulose in $9 \% \mathrm{NaOH}$ and then formed cellulose fibers [8, 9]. This opened up new research opportunities by directly dissolving the activated cellulose in an aqueous $\mathrm{NaOH}$ solution. Most of the above-mentioned activations carried out under appropriate conditions caused changes in the cellulose structure, supermolecular structure, and degree of polymerization, which allowed for obtaining cellulose spinning solutions. Numerous Polish, European, and American patents are evidence of the innovative solutions developed at the Institute in the Natural Polymer Fibers Group [12-16]. Our achievements have been noticed by specialists in the field of cellulose and the formation of cellulose fibers. The members of the Group carried out many international projects, for example, Biocelsol, Marie-Curie ITN, a project within the European Polysaccharide Network EPNOE, Wobama, or Elmo [17-22]. The Group has experience in forming classic cellulose fibers from alkaline cellulose solutions and cellulose fibers modified with other biopolymers, such as polysaccharides, or hydrolysates of plant proteins [22, 23] and animal proteins, such as fibroin and keratin $[24,25]$. Due to the introduction of biopolymers into the structure of cellulose fibers, the properties of the fibers, including bioactivity, were changed. A great achievement of the Group is the development of a method of forming flame retardant cellulose fibers based on alkaline cellulose solutions, characterized by high values of the limiting oxygen index (LOI) [26]. The hydrothermal cellulose activation method developed at the Institute deserves a special mention. This treatment allows for obtaining cellulose with a much lower polydispersity index, which is completely soluble in $9 \% \mathrm{NaOH}$ [27]. Currently, we provide research services in this area for industrial partners.

The carbamate or CELSOL technologies based on modified cellulose soluble in an aqueous solution of $\mathrm{NaOH}$ are still of great interest due to ecological reasons, low cost, and the possibility of using an existing viscose machinery and equipment.

The most advanced technology for the production of cellulose fibers-the Lyocell method-based on the solvent $\mathrm{N}$-Methylmorpholine-N-oxide (NMMO) should also be mentioned. In the Institute of Biopolymers and Chemical Fibers research was conducted into the production of cellulose 
nonwovens directly from cellulose solutions in NMMO by pneumo-thermal spinning method. High-strength Lyocell cellulose fibers are produced by the world leader in fiber production, Lenzing AG, Austria [28, 29]. Currently, these fibers and products are also available in the Polish market.

Worth mentioning is the latest technology for the production of cellulose fibers based on ionic liquids (IL) as cellulose solvents. Since the discovery of an ionic liquid as a cellulose solvent by Roger in 2002, and the preparation of a cellulose spinning solution in an ionic liquid and the production of fibers by Swatloski, one can speak of a new alternative method of fiber formation [30]. Currently, Prof. Sixta from Aalto University, Finland, is developing the loncell-F technology based on IL [29]. Cellulose fibers obtained with this technology are characterized by tensile strength above $56 \mathrm{cN} / \mathrm{tex}$. This promising and safe for the environment technology allows the production of new generation cellulose fibers. From cellulose solutions in IL, it is possible to form fibers and high-strength films [17, 20, 31].

\section{Chitosan fibers}

At the beginning of the 1990s, the Natural Polymer Fibers Group at Institute of Biopolymers and Chemical Fibers made the first attempts to form chitosan fibers and developed a method of forming fibers from chitosan derived from krill produced at the Sea Fishing Institute in Gdynia, Poland $[32,33]$. In the following years, commercial chitosans with suitable fiber-forming properties have been sought. It was only discovered during the development of microfibrids from natural polymers that the properties of chitosan, the homogeneity of its molecular weight, and the degree of deacetylation influence the quality of the spinning solution [34]. During the dissolution of chitosan, the presence of micro-gels in the spinning solution was observed. The selection of high-quality chitosan and the development of suitable conditions for the preparation of spinning solutions and coagulation allowed for the formation of continuous multifilament chitosan fibers made the Institute of Biopolymers and Chemical Fibers a leader among manufacturers of chitosan fibers. Chitosan yarn was used for knitting partially resorbable surgical mesh [35, 36]. The research was so interesting that, after establishing cooperation with Partners, the production of chitosan fibers with the assumed properties was commissioned. While carrying out the research into modifying chitosan fibers, interesting results were obtained by modifying chitosan fibers with fibroin, keratin, and collagen [37-39]. A very important stage of our research was the development of a technology for forming alginatechitosan fibers [40]. After publishing the results, the Institute established contacts with an industrial company that tested the suitability of the supplied chitosan for the production of continuous chitosan fibers. During the research project, the conditions for the preparation of the chitosan solution and the fiber-forming conditions were developed to obtain continuous chitosan fibers with satisfactory mechanical properties [5]. As part of the project, the production of functional chitosan fibers modified with nanoparticles was developed [41-43]. The introduction of carbon nanotubes had a positive effect on the increase in tensile strength up to $30 \mathrm{cN} / \mathrm{tex}$. An innovative method of producing hydroxyapatite nanoparticles in chitosan solution was developed, and then hydroxyapatite modified chitosan fibers were formed [42-44]. The obtained fibers were characterized by higher wet strength values and the 100 -fold higher calcium content. The content of calcium phosphates in chitosan fibers positively influences their suitability for medical applications [45]. The silver nanoparticles were introduced into the chitosan solution, from which the chitosan fibers containing $40 \mathrm{ppm}$ silver were formed, which were characterized by bactericidal and bacteriostatic properties against gram-positive and gram-negative bacteria. Staple and continuous chitosan fibers modified with nanoparticles were used to produce chitosan nonwovens and chitosan knitted fabrics [46, 47]. Nonwovens and knitted fabrics with appropriate mechanical and barrier properties were obtained. The production of special chitosan fibers in the form of a bundle of elementary filaments arranged in parallel allowed for the construction of a peripheral nerve prosthesis in cooperation with the Medical University of Silesia, Katowice, Poland. It has been found out that the growth of nerve cells on chitosan fibers in the prosthesis is very promising $[48,49]$.

\section{Conclusions}

- In the new Action Plan of the EU, concerning the circular economy for a greener and more competitive Europe, the European Commission announced that it would undertake initiatives to restore natural resources to the economy, and concerning the entire life cycle of products, from the design and production stage to their use, repair, reuse, and recycling.

- A circular economy model, where value and resources remain in the economy for as long as possible and the generation of waste is limited, reduces pressure on natural resources and encourages the production of biodegradable products, as well as environmental protection, including, in particular, respect for biodiversity.

- The Action Plan adopted a number of proposals for a range of industries for which a comprehensive policy framework was announced that will aim to strengthen industrial competitiveness and eco-innovation by supporting the EU market for more durable products and the re-use of waste to make new products.

- Natural polymers play an important role among biodegradable products, whose role in the production and international trade has been systematically increasing, especially since the middle of the last decade of the new century (2015).

- The global exports of natural polymers in the latest years of 2018-2019 where data is available amounted to approximately USD 2 billion and showed a growing tendency. The first group of the 20 largest exporters of these polymers in the last analyzed year 2019 was China, the USA, Sweden, France, Italy, Germany, Netherlands, Japan, Spain, Denmark, Singapore, Czech Republic, Belgium, 
Canada, Thailand Israel, Switzerland, South Korea, Brazil, and Poland.

- It should be emphasized that the dominant position in the global market of natural polymers was held by China, the USA, and Sweden (totaling an almost $56 \%$ share in it), and after additionally including the exports of France, Italy, Germany, and the Netherlands, the total share in the global market of the above-mentioned countries exceeded $80 \%$.

- The EU (27) is one of the leading players in the global export market of natural polymers, with almost half of the share (50\%) among all countries in the world in 2019 . The market leaders in the EU were three countries, i.e., Sweden, France, and Italy (the total share of these countries in the EU export of natural polymers amounted to $31.3 \%$ ). The following eight countries were among the next group of the largest exporters of natural polymers in the EU: Germany, the Netherlands, Spain, Denmark, the Czech Republic, Belgium, and Poland (on a par with Ireland).

- Poland is one of the major exporters of natural polymers, reaching the twentieth position in world exports in 2019, with high export dynamics in 2019 compared to the previous year, exceeding $18 \%$.

- The role of the Institute of Biopolymers and Chemical Fibers in the field of research and commercialization of natural polymers is leading in Poland, which is confirmed by numerous publications and research projects on a national and international scale.

\section{References}

[1] PL160866 (1989). Sposób wytwarzania karbaminianu celulozy.

[2] Kamide, K., Okajima, K. (1987). pat. USA 4634470.

[3] Yamashiki, T., Matsui, T., Kowsaka, K., Saitoh, M., Okajima, $K$., et al. (1992). New class of cellulose fibres spun from the novel solutions of cellulose by wet spinning method. Journal of Applied Polymer Science, 44(4), 691-698.

[4] PL188788 (1997). Sposób wytwarzania włókien, folii i innych produktów z alkalicznych roztworów celulozy.

[5] PL167776B (1991). Sposób wytwarzania włókien, folii $i$ innych produktów z rozpuszczalnej celulozy.

[6] EP1228098 (2000). Method for the manufacture of fibres, film and other products from modified soluble cellulose.

[7] EP1317573 (2000). Process for producing fibres, film, casings and other products from modified soluble cellulose.

[8] Kuzmina, O., Sashina, E., Troshenkowa, S., Wawro, D. (2010). Dissolved state of cellulose in ionic liquids - the impact of water. Fibres \& Textiles in Eastern Europe, 18(3), 32-37.

[9] Wawro, D., Stęplewski, W., Madaj, W., Michud, A., Hummel, M., Sixta, H. 2015). Impact of water in the casting of cellulosic film from ionic liquid solutions. Fibres \& Textiles in Eastern Europe, 23, 4(112), 25-32.

[10] US6106763 (2000). Process for producing cellulose mouldings.
[11] Wendler, F., Meister, F., Wawro, D., Wesołowska, E., Ciechańska, D., et al. (2010). Polysaccharide blend fibres formed from $\mathrm{NaOH}$, N-methylmorpholine- $\mathrm{N}$-oxide and 1-Ethyl-3-methylimidazolium acetate. Fibres \& Textiles in Eastern Europe, 18(2), 21-30.

[12] PL159089 (1989). Sposób wytwarzania karbaminianu celulozy.

[13] Wawro, D., Hummel, M., Michud, A., Sixta, H. (2014). Strong cellulosic film cast from ionic liquid solutions. Fibres \& Textiles in Eastern Europe, 22, 3(105), 35-42.

[14] Kuzmina, O., Jankowski, S., Fabianska, A., Sashina, E., Wawro, D. (2014). Preswelling of cellulose pulp for dissolution in ionic liquid. Cellulose Chemistry and Technology, 48 (1-2), 45-51.

[15] Ek, M., Chirat, C., Li, D., Iversen, T., Malmström, E., et al. (2014). WOBAMA - Wood based materials and fuels. 13th European Workshop on Lignocellulosics and Pulp, June, 24-27, 2014 - Seville, Spain.

[16] Wawro, D, Stęplewski, W. (2010). Producing of continuous cellulose fibres modified with plant proteins. Fibres \& Textiles in Eastern Europe, 18(6), 32-38.

[17] Strobin, G., Wawro, D., Stęplewski, W., Ciechanska, D., Jóźwicka J, et al. (2006). Formation of cellulose/silk-fibroin blended fibres. Fibres \& Textiles in Eastern Europe, 14(4), 32-35.

[18] Wrzesniewska-Tosik, K., Wawro, D., Ratajska, M., Włodzimierz, S. (2007). Novel biocomposites with feather keratin. Fibres \& Textiles in Eastern Europe, 15(5-6), 157162.

[19] Stęplewski, W., Kazimierczak, J., Wawro, D. (2010). Novel method of preparing flame retardant cellulose-silicate fibres. Fibres \& Textiles in Eastern Europe, 18(3), 24-31.

[20] Wawro, D., Stęplewski, W., Bodek A. (2009). Manufacture of cellulose fibres from alkaline solutions of hydrothermallytreated cellulose pulp. Fibres \& Textiles in Eastern Europe, 17(3), 18-22.

[21] Łaszkiewicz, B. (Ed.) (1997). Wytwarzanie włókien celulozowych bez udziału dwusiarczku węgla (The manufacture of cellulosic fibres without carbon disulfite). A.C.G.M. Lodart S.A., Łódź.

[22] Sixta, H., Michud, A., Hauru, L., Asaadi, S., Ma, Y., et al. (2015). A high strenght regenerated cellulose fibres, Special issue: Cellulose dissolution and regeneration: systems and interactions. Nordic Pulp \& Paper Research Journal, 30(1).

[23] PL169310B (1992). Sposób regeneracji włókien, folii $i$ innych produktów z karbaminianu celulozy.

[24] Swatloski, R. P., Spear, S. K., Holbrey, J. D., Rogers, R. D. (2002). Dissolutions of cellulose with ionic liquids. Journal of the American Chemical Society, 124(18), 4874-4975.

[25] Haslinger, S., Schlapp-Hackl, I., Ge, X., Wawro, D., Sixta, $H$. (2019). Cellulose films from birch pulp and cotton waste using [DBNH][OAc]. The 20th International Symposium on Wood, Fibre, and Pulping Chemistry September 9th 11th, 2019, Tokyo, Japan.

[26] PL160652 (1989). Sposób wytwarzania włókien chitozanowych.

[27] Struszczyk, H., Wawro, D., Niekraszewicz, A. (1992). Biodegradability of chitosan fibres. In: Advances in chitin and chitosan, pp. 580-585. doi: 10 1007/978-94-011-5942566 . 
[28] Wawro, D., Ciechańska, D., Stęplewski, W., Bodek, A. (2006). Chitosan microfibrids: Preparation, selected properties and application. Fibres Text East EurFibres \& Textiles in Eastern Europe 14(3), 97-101.

[29] Niekraszewicz, A., Kucharska, M., Wawro, D., Struszczyk, M. H., Rogaczewska, A. (2007). Partially resorbable hernia meshes. In: Jaworska, M. (Ed.). Progress on chemistry and application of chitin and its derivatives. Monograph, Vol. XII, Polish Chitin Society, Łódź, pp. 109-114.

[30] Niekraszewicz, A., Kucharska, M., Wawro, D., Kazimierz, K., Rogaczewska, A. et al. (2007). Development of a manufacturing method for surgical meshes modified by Chitosan. Fibres \& Textiles in Eastern Europe, 15(3), 105109.

[31] Strobin, G., Ciechańska, D., Wawro, D., Stęplewski, W., Jóźwicka, J., et al. (2007). Chitosan fibres modified by fibroin. Fibres \& Textiles in Eastern Europe, 15(5-6), 146148.

[32] Wawro, D., Stęplewski, W., Wrześniewska-Tosik, K. (2009). Preparation of keratin-modified chitosan fibres. Fibres \& Textiles in Eastern Europe, 17(4), 37-42.

[33] Wawro, D., Stęplewski, W., Brzoza-Malczewska, K., Święszkowski, W. (2012). Collagen-modified chitosan fibres intended for scaffolds. Fibres \& Textiles in Eastern Europe, 20(6B), 96.

[34] PL166969B (1991). Sposób wytwarzania włókien celulozowych z karbaminianu celulozy.

[35] Stęplewski, W., Wawro, D., Niekraszewicz, A., Ciechanska, D. (2006). Research into the process of manufacturing alginate-chitosan fibres. Fibres \& Textiles in Eastern Europe, 14(4), 25-31.

[36] Wawro, D., Stęplewski, W., Dymel, M., Sobczak, S., Skrzetuska, E., et al. (2012). Antibacterial chitosan fibres with content of silver nanoparticles. Fibres \& Textiles in Eastern Europe, 20, 6B(96), 24-31.

[37] Pighinelli, L., Kucharska, M., Wawro, D. (2012). Preparation of microcrystalline chitosan. Monography, Lambert Academic Publishing.

[38] PL393022 (2010). Method for producing composite chitosan fibres.

[39] Wawro, D., Pighinelli, L. (2011). Chitosan fibres modified with HAp/beta-TCP nanoparticles. International Journal of Molecular Sciences, 12(11), 7286-7300.

[40] Pighinelli, L., Wawro, D., Guimarães, M. F., Paz, R. L., Zanin, G., et al. (2018). Functional biocomposites of calcium phosphate-chitosan and its derivatives for hard tissue regeneration short review. In: Thakur, V., Thakur, M. (Eds). Functional biopolymers. Springer Series on Polymer and Composite Materials.
[41] Wawro, D., Skrzetuska, E., Włodarczyk, B., Kowalski, K., Krucińska, I. (2016). Processing of chitosan yarn into knitted fabrics. Fibres \& Textiles in Eastern Europe, 24, 6(120), 8-14. doi: 10.5604/12303666.1215538.

[42] Wawro, D., Stęplewski, W., Marcol, W., Skrzetuska, E., Krucińska I. (2019). Chitosan nonwoven - preparation and properties. Progress on Chemistry and Application of Chitin and its Derivatives, Volume XXIV.

[43] Wlaszczuk, A., Marcol, M., Kucharska, M., Wawro, D., Palen, P., et al. (2016). PLGA tubes with multifilament chitosan yarn or chitosan sponge core in nerve regeneration. Journal of Oral and Maxillofacial Surgery, 74(11), 2327.e1-2327.e12.

[44] P.419943. (2019). Proteza z rdzeniem chitozanowym do regeneracji nerwów i sposób jej wytwarzania.

[45] Mikolajczyk, T., Mikolajczyk, W., Wawro, D. (1999). Effect of a stabiliser on changes in the rheological properties of cellulose carbamate spinning solutions during their storage. Fibres \& Textiles in Eastern Europe, 7(2), 46-48.

[46] Wysokinska, Z. (2020). elaboration of the market analysis based on: Comtrade Database, SITC rev. 4; Web site: https://comtrade.un.org/data/. (Accessed on 2020.10.27).

[47] Struszczyk, H., Urbanowski, A. (1993). New Method for Manufacture of Cellulose Carbamate. Fibres \& Textiles in Eastern Europe, 1, 28.

[48] Wawro, D., Struszczyk, H. (1998). Alkaline Solutions of Cellulose and Its Derivatives, I. Studies of Alkaline Solutions of Cellulose Carbamate. Fibres \& Textiles in Eastern Europe, 1, 20.

[49] Urbanowski, A. (1996). Cellulose Carbamate a new raw materials for the manufacture of cellulose fibres. Chemical Fibres International, 46(4), 260.

[50] Ciechańska, D., Wesołowska, E., Wawro, D. (2009). An introduction to cellulosic fibres. In: Eichhorn, S., Hearle, J. W. S., Jaffe, M., Kikutani, T. (Eds.). Handbook of textile fibre structure: Natural, regenerated, inorganic and specialist fibres (Volume 2), Woodhead Textiles Series, Part 1 "Natural Fibres". pp. 3-61. 


\section{STATISTICAL ANNEX}

Table 1. World exports (of main group of 78 exporters) of natural polymers and modified natural polymers (code 57595), n.e.s. (USD, \%)- ranking for 2019

\begin{tabular}{|c|c|c|c|c|c|c|}
\hline No. & Country & 2018 & 2019 & $\begin{array}{c}\text { Dynamics } \\
2019 \text { vs. } \\
2018\end{array}$ & Share 2018 & Share 2019 \\
\hline 1 & China & 461093563 & 480067312 & $4.1 \%$ & $23.7 \%$ & $23.9 \%$ \\
\hline 2 & USA & 333231588 & 330990990 & $-0.7 \%$ & $17.1 \%$ & $16.5 \%$ \\
\hline 3 & Sweden & 283004858 & 310628639 & $9.8 \%$ & $14.6 \%$ & $15.5 \%$ \\
\hline 4 & France & 181818439 & 170405909 & $-6.3 \%$ & $9.4 \%$ & $8.5 \%$ \\
\hline 5 & Italy & 119309213 & 147090475 & $23.3 \%$ & $6.1 \%$ & $7.3 \%$ \\
\hline 6 & Germany & 94406708 & 88885653 & $-5.8 \%$ & $4.9 \%$ & $4.4 \%$ \\
\hline 7 & Netherlands & 80656751 & 84696331 & $5.0 \%$ & $4.2 \%$ & $4.2 \%$ \\
\hline 8 & Japan & 57550445 & 50096761 & $-13.0 \%$ & $3.0 \%$ & $2.5 \%$ \\
\hline 9 & Spain & 58405336 & 47276641 & $-19.1 \%$ & $3.0 \%$ & $2.4 \%$ \\
\hline 10 & Denmark & 37354846 & 41636364 & $11.5 \%$ & $1.9 \%$ & $2.1 \%$ \\
\hline 11 & Singapore & 32348702 & 39234329 & $21.3 \%$ & $1.7 \%$ & $2.0 \%$ \\
\hline 12 & Czechia & 34866719 & 34987319 & $0.3 \%$ & $1.8 \%$ & $1.7 \%$ \\
\hline 13 & Belgium & 23940786 & 24751998 & $3.4 \%$ & $1.2 \%$ & $1.2 \%$ \\
\hline 14 & Canada & 19890786 & 20189974 & $1.5 \%$ & $1.0 \%$ & $1.0 \%$ \\
\hline 15 & Thailand & 13043960 & 18922149 & $45.1 \%$ & $0.7 \%$ & $0.9 \%$ \\
\hline 16 & Israel & 2253000 & 10731000 & $376.3 \%$ & $0.1 \%$ & $0.5 \%$ \\
\hline 17 & Switzerland & 11733714 & 10433075 & $-11.1 \%$ & $0.6 \%$ & $0.5 \%$ \\
\hline 18 & Rep. of Korea & 10486650 & 10304421 & $-1.7 \%$ & $0.5 \%$ & $0.5 \%$ \\
\hline 19 & Brazil & 8711672 & 7797962 & $-10.5 \%$ & $0.4 \%$ & $0.4 \%$ \\
\hline 20 & Poland & 5833213 & 6894014 & $18.2 \%$ & $0.3 \%$ & $0.3 \%$ \\
\hline 21 & United Kingdom & 8815477 & 6702236 & $-24.0 \%$ & $0.5 \%$ & $0.3 \%$ \\
\hline 22 & India & 6656957 & 6562373 & $-1.4 \%$ & $0.3 \%$ & $0.3 \%$ \\
\hline 23 & Ireland & 2494607 & 6110487 & $144.9 \%$ & $0.1 \%$ & $0.3 \%$ \\
\hline 24 & Indonesia & 8201728 & 5240546 & $-36.1 \%$ & $0.4 \%$ & $0.3 \%$ \\
\hline 25 & Russian Federation & 727030 & 4323190 & $494.6 \%$ & $0.0 \%$ & $0.2 \%$ \\
\hline \multicolumn{2}{|c|}{ TOTALWORLD exports from 78 exporters } & 1943227973 & 2004487587 & $3.2 \%$ & $100.0 \%$ & $100.0 \%$ \\
\hline
\end{tabular}

Notes:

n.e.s. - not elsewhere specified

: data not available

Poland bolded

Source: Own elaboration based on: Comtrade Database, SITC rev. 4; https://comtrade.un.org/data/; date of access: 2020.10 .27 
Table 2. EU-27 exports -of natural polymers and modified natural polymers (code 57595), n.e.s. (USD, \%) - ranking for 2019

\begin{tabular}{|c|c|c|c|c|c|c|c|c|}
\hline No. & Country & 2018 & 2019 & $\begin{array}{c}\text { Dynamics } \\
2019 \text { vs. } 2018\end{array}$ & $\begin{array}{l}\text { Share } \\
2018^{*}\end{array}$ & $\begin{array}{l}\text { Share } \\
\text { 2019* }\end{array}$ & $\begin{array}{c}\text { Share } \\
\text { in world } \\
\text { total } 2018\end{array}$ & $\begin{array}{c}\text { Share } \\
\text { in world } \\
\text { total } 2019\end{array}$ \\
\hline 1 & Sweden & 283004858 & 310628639 & $9.8 \%$ & $30.2 \%$ & $31.8 \%$ & $14.6 \%$ & $15.5 \%$ \\
\hline 2 & France & 181818439 & 170405909 & $-6.3 \%$ & $19.4 \%$ & $17.5 \%$ & $9.4 \%$ & $8.5 \%$ \\
\hline 3 & Italy & 119309213 & 147090475 & $23.3 \%$ & $12.7 \%$ & $15.1 \%$ & $6.1 \%$ & $7.3 \%$ \\
\hline 4 & Germany & 94406708 & 88885653 & $-5.8 \%$ & $10.1 \%$ & $9.1 \%$ & $4.9 \%$ & $4.4 \%$ \\
\hline 5 & Netherlands & 80656751 & 84696331 & $5.0 \%$ & $8.6 \%$ & $8.7 \%$ & $4.2 \%$ & $4.2 \%$ \\
\hline 6 & Spain & 58405336 & 47276641 & $-19.1 \%$ & $6.2 \%$ & $4.8 \%$ & $3.0 \%$ & $2.4 \%$ \\
\hline 7 & Denmark & 37354846 & 41636364 & $11.5 \%$ & $4.0 \%$ & $4.3 \%$ & $1.9 \%$ & $2.1 \%$ \\
\hline 8 & Czechia & 34866719 & 34987319 & $0.3 \%$ & $3.7 \%$ & $3.6 \%$ & $1.8 \%$ & $1.7 \%$ \\
\hline 9 & Belgium & 23940786 & 24751998 & $3.4 \%$ & $2.6 \%$ & $2.5 \%$ & $1.2 \%$ & $1.2 \%$ \\
\hline 10 & Poland & 5833213 & 6894014 & $18.2 \%$ & $0.6 \%$ & $0.7 \%$ & $0.3 \%$ & $0.3 \%$ \\
\hline 11 & Ireland & 2494607 & 6110487 & $144.9 \%$ & $0.3 \%$ & $0.6 \%$ & $0.1 \%$ & $0.3 \%$ \\
\hline 12 & Estonia & 3702249 & 4109314 & $11.0 \%$ & $0.4 \%$ & $0.4 \%$ & $0.2 \%$ & $0.2 \%$ \\
\hline 13 & Portugal & 4720229 & 3280621 & $-30.5 \%$ & $0.5 \%$ & $0.3 \%$ & $0.2 \%$ & $0.2 \%$ \\
\hline 14 & Lithuania & 2283537 & 1882990 & $-17.5 \%$ & $0.2 \%$ & $0.2 \%$ & $0.1 \%$ & $0.1 \%$ \\
\hline 15 & Slovenia & 767741 & 1116091 & $45.4 \%$ & $0.1 \%$ & $0.1 \%$ & $0.0 \%$ & $0.1 \%$ \\
\hline 16 & Slovakia & 890585 & 546541 & $-38.6 \%$ & $0.1 \%$ & $0.1 \%$ & $0.0 \%$ & $0.0 \%$ \\
\hline 17 & Romania & 233172 & 416978 & $78.8 \%$ & $0.0 \%$ & $0.0 \%$ & $0.0 \%$ & $0.0 \%$ \\
\hline 18 & Hungary & 332470 & 328538 & $-1.2 \%$ & $0.0 \%$ & $0.0 \%$ & $0.0 \%$ & $0.0 \%$ \\
\hline 19 & Greece & 716127 & 323064 & $-54.9 \%$ & $0.1 \%$ & $0.0 \%$ & $0.0 \%$ & $0.0 \%$ \\
\hline 20 & Finland & 126651 & 277081 & $118.8 \%$ & $0.0 \%$ & $0.0 \%$ & $0.0 \%$ & $0.0 \%$ \\
\hline 21 & Cyprus & 27221 & 248006 & $811.1 \%$ & $0.0 \%$ & $0.0 \%$ & $0.0 \%$ & $0.0 \%$ \\
\hline 22 & Croatia & 398416 & 213461 & $-46.4 \%$ & $0.0 \%$ & $0.0 \%$ & $0.0 \%$ & $0.0 \%$ \\
\hline 23 & Bulgaria & 151780 & 59323 & $-60.9 \%$ & $0.0 \%$ & $0.0 \%$ & $0.0 \%$ & $0.0 \%$ \\
\hline 24 & Latvia & 36087 & 56619 & $56.9 \%$ & $0.0 \%$ & $0.0 \%$ & $0.0 \%$ & $0.0 \%$ \\
\hline 25 & Malta & $:$ & 148 & : & $0.0 \%$ & $0.0 \%$ & $0.0 \%$ & $0.0 \%$ \\
\hline 26 & Austria & $:$ & : & : & : & $:$ & $0.0 \%$ & $0.0 \%$ \\
\hline 27 & Luxembourg & 329356 & : & $-100.0 \%$ & $0.0 \%$ & $0.0 \%$ & $0.0 \%$ & $0.0 \%$ \\
\hline \multicolumn{2}{|c|}{ TOTAL EU-27 EXPORT } & 936807097 & 976222605 & $4.2 \%$ & $100.0 \%$ & $100.0 \%$ & $48.2 \%$ & $48.7 \%$ \\
\hline
\end{tabular}

Notes:

* - share in total EU-27 export

n.e.s. - not elsewhere specified

: data not available

Poland bolded

Source: Own elaboration based on: Comtrade Database, SITC rev. 4; https://comtrade.un.org/data/; date of access: 2020.10 .27 
Table 3. EU-27 imports of natural polymers and modified natural polymers (code 57595), n.e.s. (USD, \%) - ranking for 2019

\begin{tabular}{|c|c|c|c|c|c|c|c|c|}
\hline No. & Country & 2018 & 2019 & $\begin{array}{c}\text { Dynamics } \\
2019 \text { vs. } \\
2018\end{array}$ & $\begin{array}{l}\text { Share } \\
2018^{*}\end{array}$ & $\begin{array}{l}\text { Share } \\
\text { 2019* }\end{array}$ & $\begin{array}{l}\text { Share in } \\
\text { world total } \\
2018\end{array}$ & $\begin{array}{l}\text { Share in } \\
\text { world total } \\
2019\end{array}$ \\
\hline 1 & Germany & 147751673 & 152073643 & $2.9 \%$ & $21.4 \%$ & $21.4 \%$ & $6.9 \%$ & $6.9 \%$ \\
\hline 2 & France & 118550612 & 118752013 & $0.2 \%$ & $17.2 \%$ & $16.7 \%$ & $5.5 \%$ & $5.4 \%$ \\
\hline 3 & Belgium & 77432927 & 85453232 & $10.4 \%$ & $11.2 \%$ & $12.0 \%$ & $3.6 \%$ & $3.9 \%$ \\
\hline 4 & Netherlands & 76781816 & 78776317 & $2.6 \%$ & $11.1 \%$ & $11.1 \%$ & $3.6 \%$ & $3.6 \%$ \\
\hline 5 & Spain & 56007162 & 61349792 & $9.5 \%$ & $8.1 \%$ & $8.6 \%$ & $2.6 \%$ & $2.8 \%$ \\
\hline 6 & Italy & 59998802 & 59994109 & $0.0 \%$ & $8.7 \%$ & $8.4 \%$ & $2.8 \%$ & $2.7 \%$ \\
\hline 7 & Sweden & 17298261 & 22829132 & $32.0 \%$ & $2.5 \%$ & $3.2 \%$ & $0.8 \%$ & $1.0 \%$ \\
\hline 8 & Poland & 18431303 & 19611995 & $6.4 \%$ & $2.7 \%$ & $2.8 \%$ & $0.9 \%$ & $0.9 \%$ \\
\hline 9 & Austria & 19994543 & 18257903 & $-8.7 \%$ & $2.9 \%$ & $2.6 \%$ & $0.9 \%$ & $0.8 \%$ \\
\hline 10 & Denmark & 14635564 & 16686162 & $14.0 \%$ & $2.1 \%$ & $2.3 \%$ & $0.7 \%$ & $0.8 \%$ \\
\hline 11 & Slovenia & 8333332 & 12419966 & $49.0 \%$ & $1.2 \%$ & $1.7 \%$ & $0.4 \%$ & $0.6 \%$ \\
\hline 12 & Czechia & 11481496 & 10565529 & $-8.0 \%$ & $1.7 \%$ & $1.5 \%$ & $0.5 \%$ & $0.5 \%$ \\
\hline 13 & Romania & 4166491 & 10041453 & $141.0 \%$ & $0.6 \%$ & $1.4 \%$ & $0.2 \%$ & $0.5 \%$ \\
\hline 14 & Ireland & 22407166 & 7635187 & $-65.9 \%$ & $3.2 \%$ & $1.1 \%$ & $1.0 \%$ & $0.3 \%$ \\
\hline 15 & Estonia & 6598168 & 7624522 & $15.6 \%$ & $1.0 \%$ & $1.1 \%$ & $0.3 \%$ & $0.3 \%$ \\
\hline 16 & Finland & 6425380 & 6840360 & $6.5 \%$ & $0.9 \%$ & $1.0 \%$ & $0.3 \%$ & $0.3 \%$ \\
\hline 17 & Hungary & 4885312 & 5117802 & $4.8 \%$ & $0.7 \%$ & $0.7 \%$ & $0.2 \%$ & $0.2 \%$ \\
\hline 18 & Greece & 6007628 & 4842815 & $-19.4 \%$ & $0.9 \%$ & $0.7 \%$ & $0.3 \%$ & $0.2 \%$ \\
\hline 19 & Portugal & 2989949 & 4223718 & $41.3 \%$ & $0.4 \%$ & $0.6 \%$ & $0.1 \%$ & $0.2 \%$ \\
\hline 20 & Bulgaria & 2919022 & 2824295 & $-3.2 \%$ & $0.4 \%$ & $0.4 \%$ & $0.1 \%$ & $0.1 \%$ \\
\hline 21 & Lithuania & 1967605 & 2048906 & $4.1 \%$ & $0.3 \%$ & $0.3 \%$ & $0.1 \%$ & $0.1 \%$ \\
\hline 22 & Croatia & 1360074 & 1073551 & $-21.1 \%$ & $0.2 \%$ & $0.2 \%$ & $0.1 \%$ & $0.0 \%$ \\
\hline 23 & Slovakia & 2442639 & 1039448 & $-57.4 \%$ & $0.4 \%$ & $0.1 \%$ & $0.1 \%$ & $0.0 \%$ \\
\hline 24 & Latvia & 528849 & 544490 & $3.0 \%$ & $0.1 \%$ & $0.1 \%$ & $0.0 \%$ & $0.0 \%$ \\
\hline 25 & Malta & 87379 & 197587 & $126.1 \%$ & $0.0 \%$ & $0.0 \%$ & $0.0 \%$ & $0.0 \%$ \\
\hline 26 & Cyprus & 614619 & 73447 & $-88.0 \%$ & $0.1 \%$ & $0.0 \%$ & $0.0 \%$ & $0.0 \%$ \\
\hline 27 & Luxembourg & 121427 & : & : & $0.0 \%$ & : & $0.0 \%$ & : \\
\hline \multicolumn{2}{|c|}{ TOTAL EU-27 IMPORT } & 690219199 & 710897374 & $3.0 \%$ & $100.0 \%$ & $100.0 \%$ & $32.2 \%$ & $32.1 \%$ \\
\hline
\end{tabular}

Notes:

* - share in total EU-27 import

n.e.s. - not elsewhere specified

: data not available

Poland bolded

Source: Own elaboration based on: Comtrade Database, SITC rev. 4; https://comtrade.un.org/data/; date of access: 2020.10 .27 
Table 4. Exports from Poland to the main Polish world recipients of natural polymers and modified natural polymers (code 57595), n.e.s. (USD, $\%)$ - ranking for 2019

\begin{tabular}{|c|c|c|c|c|c|c|}
\hline No. & Country & 2018 & 2019 & $\begin{array}{c}\text { Dynamics 2019- } \\
2018\end{array}$ & $\begin{array}{l}\text { Share } \\
2018\end{array}$ & $\begin{array}{l}\text { Share } \\
2019\end{array}$ \\
\hline 1 & Germany & 563820 & 984459 & $74.6 \%$ & $9.7 \%$ & $14.3 \%$ \\
\hline 2 & Denmark & 588312 & 774498 & $31.6 \%$ & $10.1 \%$ & $11.2 \%$ \\
\hline 3 & United Kingdom & 235611 & 735927 & $212.3 \%$ & $4.0 \%$ & $10.7 \%$ \\
\hline 4 & United Arab Emirates & 270593 & 728383 & $169.2 \%$ & $4.6 \%$ & $10.6 \%$ \\
\hline 5 & Mexico & 482072 & 547807 & $13.6 \%$ & $8.3 \%$ & $7.9 \%$ \\
\hline 6 & Czechia & 129482 & 514975 & $297.7 \%$ & $2.2 \%$ & $7.5 \%$ \\
\hline 7 & France & 532302 & 372596 & $-30.0 \%$ & $9.1 \%$ & $5.4 \%$ \\
\hline 8 & Spain & 686114 & 300937 & $-56.1 \%$ & $11.8 \%$ & $4.4 \%$ \\
\hline 9 & Russian Federation & 775122 & 221401 & $-71.4 \%$ & $13.3 \%$ & $3.2 \%$ \\
\hline 10 & Belarus & 23672 & 207318 & $775.8 \%$ & $0.4 \%$ & $3.0 \%$ \\
\hline 11 & Italy & 98923 & 172921 & $74.8 \%$ & $1.7 \%$ & $2.5 \%$ \\
\hline 12 & Cyprus & : & 155428 & : & : & $2.3 \%$ \\
\hline 13 & Ukraine & 176560 & 140312 & $-20.5 \%$ & $3.0 \%$ & $2.0 \%$ \\
\hline 14 & Netherlands & 168650 & 123076 & $-27.0 \%$ & $2.9 \%$ & $1.8 \%$ \\
\hline 15 & Egypt & : & 104788 & : & : & $1.5 \%$ \\
\hline 16 & India & 21295 & 68882 & $223.5 \%$ & $0.4 \%$ & $1.0 \%$ \\
\hline \multicolumn{2}{|c|}{ TOTAL exports of natural polymers from Poland } & 5833213 & 6894014 & $18.2 \%$ & $100.0 \%$ & $100.0 \%$ \\
\hline
\end{tabular}

Notes:

n.e.s. - not elsewhere specified

: data not available

Source: Own elaboration based on: Comtrade Database, SITC rev. 4; https://comtrade.un.org/data/; date of access: 2020.10 .28$. 
Table 5. Exports from Poland to EU-27 countries of natural polymers and modified natural polymers (code 57595), n.e.s. (USD, \%) - ranking for 2019

\begin{tabular}{|c|c|c|c|c|c|c|}
\hline No. & Country & 2018 & 2019 & Dynamics 2019-2018 & Share 2018 & Share 2019 \\
\hline 1 & Germany & 563820 & 984459 & $74.6 \%$ & $18.1 \%$ & $26.5 \%$ \\
\hline 2 & Denmark & 588312 & 774498 & $31.6 \%$ & $18.9 \%$ & $20.8 \%$ \\
\hline 3 & Czechia & 129482 & 514975 & $297.7 \%$ & $4.2 \%$ & $13.8 \%$ \\
\hline 4 & France & 532302 & 372596 & $-30.0 \%$ & $17.1 \%$ & $10.0 \%$ \\
\hline 5 & Spain & 686114 & 300937 & $-56.1 \%$ & $22.1 \%$ & $8.1 \%$ \\
\hline 6 & Italy & 98923 & 172921 & $74.8 \%$ & $3.2 \%$ & $4.6 \%$ \\
\hline 7 & Cyprus & : & 155428 & : & : & $4.2 \%$ \\
\hline 8 & Netherlands & 168650 & 123076 & $-27.0 \%$ & $5.4 \%$ & $3.3 \%$ \\
\hline 9 & Malta & : & 55965 & : & $:$ & $1.5 \%$ \\
\hline 10 & Estonia & 47955 & 49106 & $2.4 \%$ & $1.5 \%$ & $1.3 \%$ \\
\hline 11 & Hungary & 46545 & 46320 & $-0.5 \%$ & $1.5 \%$ & $1.2 \%$ \\
\hline 12 & Bulgaria & 55659 & 40930 & $-26.5 \%$ & $1.8 \%$ & $1.1 \%$ \\
\hline 13 & Lithuania & 31363 & 30209 & $-3.7 \%$ & $1.0 \%$ & $0.8 \%$ \\
\hline 14 & Latvia & 22290 & 25450 & $14.2 \%$ & $0.7 \%$ & $0.7 \%$ \\
\hline 15 & Croatia & 39899 & 19663 & $-50.7 \%$ & $1.3 \%$ & $0.5 \%$ \\
\hline 16 & Austria & 12326 & 18883 & $53.2 \%$ & $0.4 \%$ & $0.5 \%$ \\
\hline 17 & Slovakia & 26619 & 15045 & $-43.5 \%$ & $0.9 \%$ & $0.4 \%$ \\
\hline 18 & Romania & 19419 & 14530 & $-25.2 \%$ & $0.6 \%$ & $0.4 \%$ \\
\hline 19 & Belgium & 5475 & 3667 & $-33.0 \%$ & $0.2 \%$ & $0.1 \%$ \\
\hline \multicolumn{2}{|r|}{ TOTAL } & 3108380 & 3719209 & $19.7 \%$ & $100.0 \%$ & $100.0 \%$ \\
\hline
\end{tabular}

Notes:

n.e.s. - not elsewhere specified

: data not available

Source: Own elaboration based on: Comtrade Database, SITC rev. 4; https://comtrade.un.org/data/; date of access: 2020.10 .27 
Table 6. EU-27 imports of natural polymers and modified natural polymers (code 57595), n.e.s. (USD, \%) - ranking for 2019

\begin{tabular}{|c|c|c|c|c|c|c|c|c|}
\hline No. & Country & 2018 & 2019 & $\begin{array}{c}\text { Dynamics } \\
2019 \text { vs. } 2018\end{array}$ & $\begin{array}{l}\text { Share } \\
\text { 2018* }\end{array}$ & $\begin{array}{l}\text { Share } \\
\text { 2019* }\end{array}$ & $\begin{array}{c}\text { Share in } \\
\text { world total } \\
2018\end{array}$ & $\begin{array}{c}\text { Share in } \\
\text { world total } \\
2019\end{array}$ \\
\hline 1 & Germany & 147751673 & 152073643 & $2.9 \%$ & $21.4 \%$ & $21.4 \%$ & $6.9 \%$ & $6.9 \%$ \\
\hline 2 & France & 118550612 & 118752013 & $0.2 \%$ & $17.2 \%$ & $16.7 \%$ & $5.5 \%$ & $5.4 \%$ \\
\hline 3 & Belgium & 77432927 & 85453232 & $10.4 \%$ & $11.2 \%$ & $12.0 \%$ & $3.6 \%$ & $3.9 \%$ \\
\hline 4 & Netherlands & 76781816 & 78776317 & $2.6 \%$ & $11.1 \%$ & $11.1 \%$ & $3.6 \%$ & $3.6 \%$ \\
\hline 5 & Spain & 56007162 & 61349792 & $9.5 \%$ & $8.1 \%$ & $8.6 \%$ & $2.6 \%$ & $2.8 \%$ \\
\hline 6 & Italy & 59998802 & 59994109 & $0.0 \%$ & $8.7 \%$ & $8.4 \%$ & $2.8 \%$ & $2.7 \%$ \\
\hline 7 & Sweden & 17298261 & 22829132 & $32.0 \%$ & $2.5 \%$ & $3.2 \%$ & $0.8 \%$ & $1.0 \%$ \\
\hline 8 & Poland & 18431303 & 19611995 & $6.4 \%$ & $2.7 \%$ & $2.8 \%$ & $0.9 \%$ & $0.9 \%$ \\
\hline 9 & Austria & 19994543 & 18257903 & $-8.7 \%$ & $2.9 \%$ & $2.6 \%$ & $0.9 \%$ & $0.8 \%$ \\
\hline 10 & Denmark & 14635564 & 16686162 & $14.0 \%$ & $2.1 \%$ & $2.3 \%$ & $0.7 \%$ & $0.8 \%$ \\
\hline 11 & Slovenia & 8333332 & 12419966 & $49.0 \%$ & $1.2 \%$ & $1.7 \%$ & $0.4 \%$ & $0.6 \%$ \\
\hline 12 & Czechia & 11481496 & 10565529 & $-8.0 \%$ & $1.7 \%$ & $1.5 \%$ & $0.5 \%$ & $0.5 \%$ \\
\hline 13 & Romania & 4166491 & 10041453 & $141.0 \%$ & $0.6 \%$ & $1.4 \%$ & $0.2 \%$ & $0.5 \%$ \\
\hline 14 & Ireland & 22407166 & 7635187 & $-65.9 \%$ & $3.2 \%$ & $1.1 \%$ & $1.0 \%$ & $0.3 \%$ \\
\hline 15 & Estonia & 6598168 & 7624522 & $15.6 \%$ & $1.0 \%$ & $1.1 \%$ & $0.3 \%$ & $0.3 \%$ \\
\hline 16 & Finland & 6425380 & 6840360 & $6.5 \%$ & $0.9 \%$ & $1.0 \%$ & $0.3 \%$ & $0.3 \%$ \\
\hline 17 & Hungary & 4885312 & 5117802 & $4.8 \%$ & $0.7 \%$ & $0.7 \%$ & $0.2 \%$ & $0.2 \%$ \\
\hline 18 & Greece & 6007628 & 4842815 & $-19.4 \%$ & $0.9 \%$ & $0.7 \%$ & $0.3 \%$ & $0.2 \%$ \\
\hline 19 & Portugal & 2989949 & 4223718 & $41.3 \%$ & $0.4 \%$ & $0.6 \%$ & $0.1 \%$ & $0.2 \%$ \\
\hline 20 & Bulgaria & 2919022 & 2824295 & $-3.2 \%$ & $0.4 \%$ & $0.4 \%$ & $0.1 \%$ & $0.1 \%$ \\
\hline 21 & Lithuania & 1967605 & 2048906 & $4.1 \%$ & $0.3 \%$ & $0.3 \%$ & $0.1 \%$ & $0.1 \%$ \\
\hline 22 & Croatia & 1360074 & 1073551 & $-21.1 \%$ & $0.2 \%$ & $0.2 \%$ & $0.1 \%$ & $0.0 \%$ \\
\hline 23 & Slovakia & 2442639 & 1039448 & $-57.4 \%$ & $0.4 \%$ & $0.1 \%$ & $0.1 \%$ & $0.0 \%$ \\
\hline 24 & Latvia & 528849 & 544490 & $3.0 \%$ & $0.1 \%$ & $0.1 \%$ & $0.0 \%$ & $0.0 \%$ \\
\hline 25 & Malta & 87379 & 197587 & $126.1 \%$ & $0.0 \%$ & $0.0 \%$ & $0.0 \%$ & $0.0 \%$ \\
\hline 26 & Cyprus & 614619 & 73447 & $-88.0 \%$ & $0.1 \%$ & $0.0 \%$ & $0.0 \%$ & $0.0 \%$ \\
\hline 27 & Luxembourg & 121427 & : & : & $0.0 \%$ & : & $0.0 \%$ & : \\
\hline \multicolumn{2}{|c|}{ TOTAL EU-27 IMPORT } & 690219199 & 710897374 & $3.0 \%$ & $100.0 \%$ & $100.0 \%$ & $32.2 \%$ & $32.1 \%$ \\
\hline
\end{tabular}

Notes:

* - share in total EU-27 import

n.e.s. - not elsewhere specified

: data not available

Source: Own elaboration based on: Comtrade Database, SITC rev. 4; https://comtrade.un.org/data/; date of access: 2020.10 .27 
Table 7. Imports of natural polymers and modified natural polymers to Poland from major global suppliers (code 57595), n.e.s. (USD, \%) - ranking for 2019

\begin{tabular}{|c|c|c|c|c|c|c|}
\hline No. & Country & 2018 & 2019 & $\begin{array}{c}\text { Dynamics 2019- } \\
2018\end{array}$ & Share 2018 & Share 2019 \\
\hline 1 & China & 3993451 & 4840246 & $21.2 \%$ & $21.7 \%$ & $24.7 \%$ \\
\hline 2 & Sweden & 2761811 & 2996518 & $8.5 \%$ & $15.0 \%$ & $15.3 \%$ \\
\hline 3 & USA & 1943332 & 2442453 & $25.7 \%$ & $10.5 \%$ & $12.5 \%$ \\
\hline 4 & Pakistan & 1428924 & 1540786 & $7.8 \%$ & $7.8 \%$ & $7.9 \%$ \\
\hline 5 & Germany & 1544267 & 1419347 & $-8.1 \%$ & $8.4 \%$ & $7.2 \%$ \\
\hline 6 & Saudi Arabia & 864556 & 1127708 & $30.4 \%$ & $4.7 \%$ & $5.8 \%$ \\
\hline 7 & France & 919290 & 870083 & $-5.4 \%$ & $5.0 \%$ & $4.4 \%$ \\
\hline 8 & Austria & 774274 & 666778 & $-13.9 \%$ & $4.2 \%$ & $3.4 \%$ \\
\hline 9 & Canada & 561900 & 551705 & $-1.8 \%$ & $3.0 \%$ & $2.8 \%$ \\
\hline 10 & Denmark & 808323 & 542107 & $-32.9 \%$ & $4.4 \%$ & $2.8 \%$ \\
\hline 11 & Italy & 761090 & 407374 & $-46.5 \%$ & $4.1 \%$ & $2.1 \%$ \\
\hline 12 & Netherlands & 302607 & 406306 & $34.3 \%$ & $1.6 \%$ & $2.1 \%$ \\
\hline 13 & Israel & 271900 & 303423 & $11.6 \%$ & $1.5 \%$ & $1.5 \%$ \\
\hline \multicolumn{2}{|r|}{ TOTAL } & 18431303 & 19611995 & $6.4 \%$ & $100.0 \%$ & $100.0 \%$ \\
\hline
\end{tabular}

\section{Notes:}

n.e.s. - not elsewhere specified

: data not available

Source: Own elaboration based on: Comtrade Database, SITC rev. 4; https://comtrade.un.org/data/; date of access: 2020.10.28. 